\title{
Ecosystem approach for natural hazard mitigation of volcanic tephra in Iceland: building resilience and sustainability
}

\author{
Anna María Ágústsdóttir ${ }^{1}$ (D)
}

Received: 19 June 2014/Accepted: 6 May 2015/Published online: 22 May 2015

(C) The Author(s) 2015. This article is published with open access at Springerlink.com

\begin{abstract}
Living in Iceland, a highly volcanically active island with a historical eruption frequency of 20-25 events per 100 years, involves risks from lava, pyroclastic flows, tephra-fall, and floods from glacier/snow-covered volcanoes. Volcanic eruptions can have detrimental effects on human health, societies, and ecosystems. Eruptions in 2010-2011 proved the value of pre-event planning for some natural hazards. An additional focus is needed on pre-disaster mitigation responses for the effects of tephra-fall on vegetation: As outlined under the UNISDR Hyogo/Sendai Framework for Action, healthy ecosystems and environmental management are key actions in disaster risk reduction (DRR). Iceland's most serious environmental problem is the degraded state of common rangeland in the highlands, where tephra-fall has been catastrophic. Tephra (airborne volcanic material) affects hydrology, air quality, and ecosystems by direct burial or post-eruptive transport, extending its influence far beyond the initial eruption area. Resilience to tephra-related disturbances depends on an ecosystem's overall health. Tall, vigorous vegetation has greater endurance; its initial survival is more likely, while sheltering minimizes secondary transport and hastens recovery. Areas that are sparsely vegetated and already stressed are more vulnerable; there, tephra remains unstable and can cause further damage. Reclaiming vulnerable land and building healthy ecosystems, as represented by the Hekluskógar project, improve the ability of these areas to endure tephra-fall, increasing their resilience and reducing the associated costs to society. Successful DRR for tephra-fall, through the revegetation of degraded land, will require effective governance, multi-sector coordination, and the alignment of policies on land use, agriculture, natural resource management, and climate change mitigation.
\end{abstract}

Keywords Disaster risk reduction · Resilience · Volcanic tephra - Governance · Policy · Sustainability analysis · Threshold · Volcanic ash · Restoration ecology · Recovery · Hazard · Communities · Wind erosion · Air quality · Human health · Ash storm ·

Anna María Ágústsdóttir annamaria@land.is

1 Soil Conservation Service of Iceland, Gunnarsholt, 851 Hella, Iceland 
Agriculture $\cdot$ Ecosystem services $\cdot$ Environmental degradation $\cdot$ Ecosystem resilience for mitigation of natural disasters - Ecosystem restoration - Hyogo framework of action . Sendai framework for disaster risk reduction $\cdot$ Ecosystem stressors $\cdot$ Mitigation

\section{Introduction}

Ecosystems in Iceland are at risk both from natural hazards and from unsustainable human activities. In terms of natural hazards, Icelanders have, since 1967 (Act nr. 30/1967), developed responses to volcanic eruptions, earthquakes, oceanic floods, snow avalanches, weather, wildfires, and glacier outburst floods (jökulhlaups) (NCIP-DCPEM 2005a). Risk management in Iceland is currently based on the "Hyogo Framework for Action, Building the Resilience of Nations and Communities to Disasters" of the UN International Strategy for Disaster Risk Reduction (UNISDR) (2013); this framework incorporates assessment, prevention, mitigation, monitoring, early warning, and preparedness. In 2005, the Civil Protection and Emergency Management team of the Icelandic National Commissioner of Police completed hazard assessment, risk analysis, and response plans regarding volcanic eruptions and associated glacier outburst floods in South Iceland (NCIP-DCPEM 2005b); these plans were followed, in 2006 , by a public awareness campaign incorporating evacuation drills for all the inhabitants of potentially threatened areas. During the next eruption (Eyjafjallajökull 2010), the response plan was successful, with respect to evacuations and all other planned mitigation measures. However, responses to the dispersal of volcanic ash, or of tephra in general, had not been included in the plan, and Iceland, along with all of Europe, was unprepared for the resulting extensive closure of airspace and the associated global economic effects. The local, regional, and global effects of tephra, defined as airborne volcanic material of any size, proved to be an important aspect of volcanic hazards left out of the otherwise successful pre-event risk management plan.

During a disaster, attention is understandably focused on direct impacts, relief, and recovery operations. Major events like the 2010 eruption of Eyjafjallajökull, however, can potentially act as thresholds, changing dominant ways of thinking and acting by placing tradition - in this case, traditional land-use patterns - under critical review (Birkmann et al. 2008). In Iceland, the 2010 tephra-fall event may create a paradigm shift toward embracing concepts of sustainability. By exploring the consequences of decisions that affect human and ecosystem integrity (Sidle et al. 2013), the potential for an ecosystem role in disaster risk reduction (DRR) for tephra-fall is revealed.

While ecosystem management is not a new concept, research is needed to maximize its benefits for DRR and to ease its uptake by communities, disaster management practitioners, policy makers, and decision makers (PEDRR 2010). Ecosystem-based DRR has been suggested for various hazards, such as landslides, flooding, avalanches, storm surges, wildfires, drought, and climate change (ProAct Network 2008; Sudmeier-Rieux and Ash 2009; World Bank 2010). With regard to volcanic eruptions, however, DRR measures have focused primarily on direct impacts, such as land-use planning in at-risk areas or effective emergency plans for the evacuation of people (EEA 2010). To reduce the indirect impacts, for example, on ecosystems, human health, or global temperature, requires measures at a supranational level. This is a more challenging issue because, as yet, there have been no quantitative evaluations of these indirect effects (EEA 2010). There exists a knowledge gap regarding ecosystem-based approaches of DRR for volcanic hazards. This article helps 
close that gap by presenting for the first time a unique approach to reducing the effects of remobilized tephra, increasing the initial survival of vegetation, and improving both social and ecosystem resilience to future tephra-fall events.

\section{Natural systems, disruptions, and resilience}

Change is a constant of natural systems. Abrupt events, such as earthquakes, severe weather, or volcanic eruptions, whether singular or repeated, often cause the largest damage to a natural system, as there is limited time for the system to adapt. Disruptions often last longer than the original event itself, initiating chain reactions that lead to further damage. This fact is well known from Iceland's eruptive history, as secondary effects have led to changes in climate, crop failure, and famine, either locally or on a larger scale; it is also known from global climate history, as abrupt events have led to the socioeconomic collapse of societies (Alley 2000; Hodell et al. 1995; Steingrímsson 1998; Thordarson and Self 2003).

A natural hazard is defined by the United Nations (UNISDR 2009) as a "Natural process or phenomenon that may cause loss of life, injury, or other health impacts, property damage, loss of livelihoods and services, social and economic disruption, or environmental damage." A disaster is a serious disruption in the functioning of a community or a society, causing widespread human, economic, or environmental losses that exceed the ability of the affected community or society to cope using its own resources (UNISDR 2009). Disaster risk reduction is important to lessen these effects through reduced exposure, lessened vulnerability of people and property, wise management of land and the environment, and improved preparedness for adverse events (Birkmann et al. 2013; UNISDR 2009).

The effects of a natural hazard depend not only on its magnitude, but also on the society's vulnerability, its culture, and its state before each event (Birkmann et al. 2013). The society's dependence upon land use in the affected areas, the distribution of the population, governance, risk perception, prior experience, and even luck can all play a role. The key to having a resilient society is the ability to absorb shocks, bounce back, learn, and adapt. Resilience has been defined by the UNISDR (2009) as: "The ability of a system, community, or society exposed to hazards to resist, absorb, accommodate to, and recover from the effects of a hazard in a timely and efficient manner, including through the preservation and restoration of its essential basic structures and functions."

Mitigation of natural hazards is vital to meet the long-term aims and multiple objectives of sustainability, i.e., safeguarding the environment as well as human living conditions, while meeting the needs of both current and future generations (El-Masri and Tipple 2002). Ecosystems contribute to reducing the risk of natural hazards in multiple ways. The extent of buffering depends on the ecosystem's health and on the intensity of the event (Bignami et al. 2012; Boyd et al. 2005; Dugmore et al. 2007). Ecosystems sustain human livelihoods and contribute to the ability of communities to withstand and recover from disasters (Millennium Ecosystem Assessment 2005). Ecosystem health is thus closely linked to the idea of sustainability, which implies the ability of the system to maintain its structure (organization) and function (vigor) over time in the face of external stress (resilience) (Costanza 1992, 2012). The term "sustainable ecosystem" implies also that resource use, or the demand for ecosystem services, does not exceed the supply for both present and future generations (Sudmeier-Rieux and Ash 2009). The state of ecosystems and their land- 
A Structures

- Private households

Summer cottages and tourist accommodations

- Power plants and utility services

- Other structures

- Urban area

Elevation in meters

(3) $1100-2100$

(1000-1100

$900-1000$

C $800-900$

$700-800$

$03600-700$

(C) 500-600

-300-500

200-400

$0-200$

B Soil erosion

3 No erosion

Little erosion Some erosion

Considerable erosion

3 Severe erosion

Extremely severe erosion

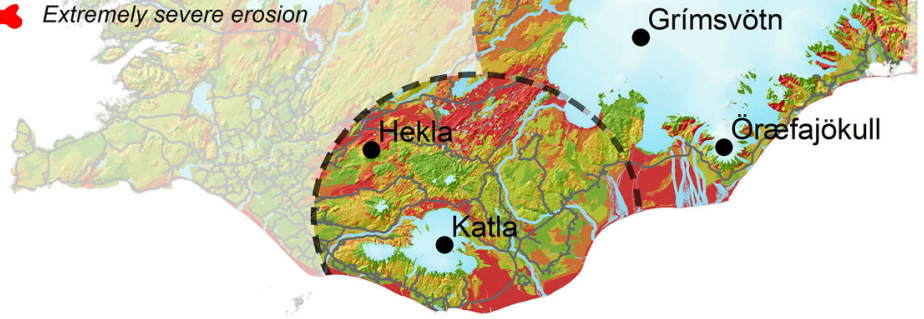

C Vegetation type

Grassland

$\square$ Richly vegetaded heath land

$\square$ Cultivated land

$\square$ Poorly vegetated land

- Shrubs and forest

$\square$ Moss land

$\square$ Semi wetland

Wetland

$\square$ Partly vegetated

Sparsly vegetated
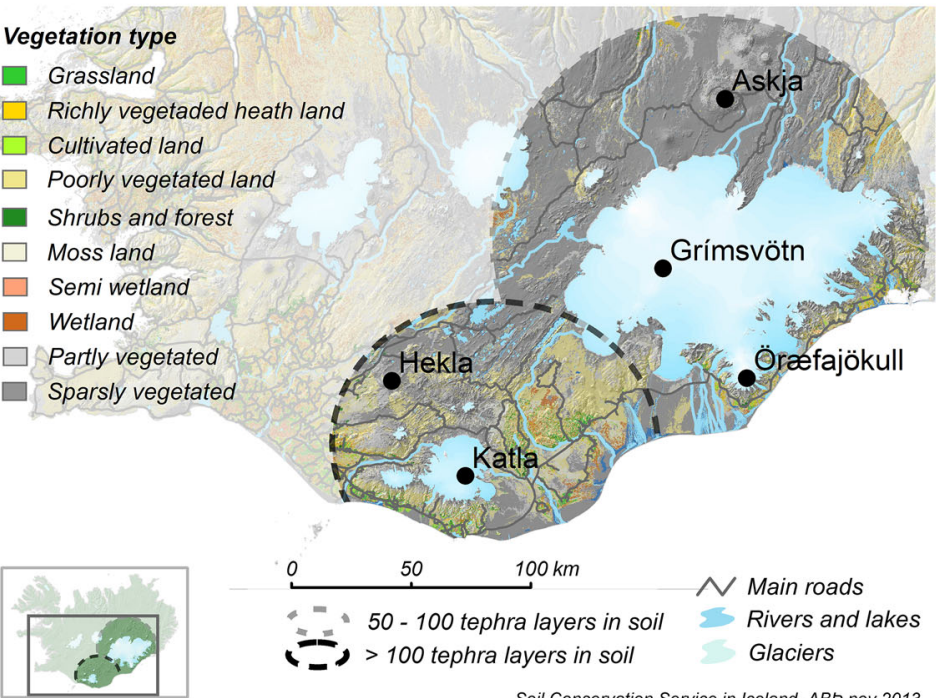

Soil Conservation Service in Iceland, ABP nov 2013 
4Fig. 1 Potential mitigation in S and SE Iceland in areas most likely to experience tephra events, based on location of most active volcanoes, frequency of tephra layers in soil (Larsen and Gíslason 2013), and prevailing wind patterns (Jónsson 1990, 2010). Circles indicate frequency of tephra layers in soil (Larsen and Gíslason 2013); a land elevation, main roads, and structures (Map Viewer 2013), b soil erosion (Arnalds et al. 2001), c vegetation (Agricultural University of Iceland 2013)

use history contribute to their resilience to tephra-fall disturbances, as the following examples from Mexico and Iceland show. The Paricutin eruption in Mexico in 1943-1953 demonstrates the effects of prior land use: In areas affected by tephra-fall, successional progress still differs according to the pre-eruptive ecosystem state 50 years after the eruption ceased. In areas with prior intense land use, such as bare agricultural fields and other barren areas, plant cover remains low $(<10 \%)$ and succession proceeds at a slower pace than in areas that were covered by forests at the time of the eruption (Lindig-Cisneros et al. 2006). An example of the effect of post-eruptive land use comes from Iceland (Dugmore et al. 2007): After the tephra-fall from an eruption of Hekla in $1104 \mathrm{AD}$, the recovery of vegetation was reduced due to continued grazing pressure, thus limiting the natural succession of the degraded ecosystem. This geomorphic instability persisted in some areas until $1300 \mathrm{AD}$. However, after the deposition of new tephra from an eruption of Hekla in $1300 \mathrm{AD}$, a change in the human impact on the area (perhaps the complete removal of grazing pressure) allowed the landscape to stabilize.

\section{Volcanic activity in Iceland}

Volcanism is prevalent in Iceland due to the island's location on the Mid-Atlantic Ridge. Active volcanic regions cover $30 \%$ of the island, with a historical (the last 1100 years) eruption frequency of 20-25 events per 100 years, or 1 every 5 years, on average (Thordarson and Larsen 2007). Risk of tephra-fall in Iceland is therefore considerable, as $78 \%$ of all historical eruptions were explosive, with tephra making up $>95 \%$ of the eruptive material (Thordarson and Larsen 2007).

Large eruptions cause widespread dispersal of tephra: Icelandic tephra is found in the $\mathrm{N}$ Atlantic Ocean, in the Norwegian Sea, and in Europe (Haflidason et al. 2000). NW European lake and peat sediments of the past 1000 years show that tephra from Iceland reached $\mathrm{N}$ Europe with a mean return interval of $56 \pm 9$ years, suggesting that, for any 10 -year period in the last millennium, there is a $16 \%$ probability of a tephra event leaving detectable deposits in N Europe (Swindles et al. 2011). The probability in Iceland is much higher, as the effects of smaller eruptions are more localized.

Explosive eruptions are more common than effusive ones, and the frequency of explosive silicic eruptions in Iceland is high, or 1 every 200-300 years. Eruptions that emit $1-10 \mathrm{~km}^{3}$ of tephra occur on average once every 1000 years, and larger events $\left(>10 \mathrm{~km}^{3}\right.$ tephra) occur roughly once in 100,000 years (Thordarson and Larsen 2007). In terms of the Volcanic Explosivity Index (VEI), there is one VEI 5 event every 100-200 years and one VEI 6 event every 500-1000 years (Gudmundsson et al. 2008). These large events are likely to deposit tephra over most of Iceland, with the greatest damage to vegetation expected within the $20-\mathrm{cm}$ isopach or $70-80 \mathrm{~km}$ from the volcano; severe damage could also occur at tephra thicknesses of less than $20 \mathrm{~cm}$. The probability of a tephra-fall event with a thickness of $>20 \mathrm{~cm}$ has been estimated as being highest in S Iceland, in the areas 
near Vík í Mýrdal (1/50), Landeyjar (1/200), Vestmannaeyjar (1/250), and Hornafjörður (1/ 1000) (Viðlagatrygging Íslands 2011).

The most active volcanic centers in Iceland are Grímsvötn, Hekla, and Katla (Fig. 1). Grímsvötn leads with 70 historical eruptions; the tephra volume per event is 0.01 to $>0.5 \mathrm{~km}^{3}$ (Thordarson and Larsen 2007). The 1783-1784 Laki (or Laki-Grímsvötn) eruption caused significant environmental and climatic effects, when $14.7 \mathrm{~km}^{3}$ of lava covered $565 \mathrm{~km}^{2}$ of land and $0.4 \mathrm{~km}^{3}$ of tephra covered $7,200 \mathrm{~km}^{2}$ within the $0.5 \mathrm{~cm}$ isopach; fine ash affected the entire island, over 100,000 km² (Thordarson and Self 1993, 2003). Sulfur release $\left(120 \mathrm{Tg}\right.$ of $\mathrm{SO}_{2}$ ) to the atmosphere caused vegetation damage across Iceland and the death of $60 \%$ of the grazing livestock, mainly due to chronic fluorosis. Widespread famine caused the death of $25 \%$ of the Icelandic population within 2 years (Snævar 1993; Steingrímsson 1998; Thordarson and Self 1993). Laki was a catastrophic disruption, especially for an isolated peripheral region, as Iceland was at the time. Similar, but less severe, impacts of this eruption were observed elsewhere in the $\mathrm{N}$ hemisphere (Thordarson and Self 2003). Eruptions such as Laki are low-probability, high-impact events. If such an event were to occur today, it would constitute a major European health hazard and likely cause an excess mortality in Europe of 29,000 in the first year and 142,000 due to long-term exposure to particles smaller than $2.5 \mu \mathrm{m}$ in diameter (Schmidt et al. 2011).

The volcano Hekla historically produced 1-2 eruptions per century until 1947 (Thorarinsson 1967), with tephra volumes of $0.01-2 \mathrm{~km}^{3}$ per event (Thordarson and Larsen 2007). The largest historical event, in $1104 \mathrm{AD}$, caused complete destruction within $70 \mathrm{~km}$; tephra blanketed half the country, with $55,000 \mathrm{~km}^{2}$ within the $0.2-\mathrm{cm}$ isopach (Gudmundsson et al. 2008; Thorarinsson 1979).

The historical eruption frequency of the third most active volcano in Iceland, Katla, has been 1-3 per century, with tephra volumes of $\sim 0.01$ to $>1 \mathrm{~km}^{3}$ per event; all these eruptions have been associated with major glacial outburst floods (Thorarinsson 1975). The total volume of erupted magma is $25 \mathrm{~km}^{3}$, making Katla (until the eruption of Bárðarbunga-Grímsvötn in 2014-2015) the most productive system in historical time (Larsen 2000; Thordarson and Larsen 2007). The largest event associated with Katla was the Eldgjá eruption of $934 \mathrm{AD}$, producing a minimum of $4 \mathrm{~km}^{3}$ of basaltic tephra (Larsen 2000).

Other examples of large explosive eruptions include the 1875 event in Askja (SE Iceland), which caused abandonment of farms within $60-70 \mathrm{~km}$ distance when $1.83 \mathrm{~km}^{3}$ of tephra erupted in $17 \mathrm{~h}$ (Carey et al. 2010; Thorarinsson 1944). The VEI 6-level eruption of Öræfajökull in 1362, the largest plinian event of the last millennium, deposited $10 \mathrm{~km}^{3}$ of tephra, causing long-term devastation of large areas in SE Iceland (Thorarinsson 1958).

Changes in volcanic activity are expected in the near future. Volcanism in Iceland has a marked periodicity; this, combined with climatic change and the correspondingly reduced surface pressure from melting glaciers, suggests that the cyclic behavior of volcanic activity is about to enter its next active phase (Larsen et al. 1998; Sigmundsson et al. 2010). There is an increased probability of activity in the E Iceland volcanic zone, where $80 \%$ of all historical eruptions have occurred and the four most active volcanoes are located (Thordarson and Larsen 2007). An eruption can be expected every 2-7 years at Grímsvötn, with parallel activity in nearby Bárðarbunga (Larsen et al. 1998; Óladóttir et al. 2011). Geophysical monitoring suggests the entry of magma beneath Hekla and the W Vatnajökull area in recent years, while for the last few decades an impending Katla eruption has been expected (IMO 2011). In 2006, the probability of a Katla eruption was estimated to be $20 \%$ within the next 10 years (Eliasson et al. 2006). The latest event is the 
2014-2015 non-explosive fissure eruption from the Bárðarbunga system (Gudmundsson et al. 2014; Sigmundsson et al. 2015). The largest effusive eruption in Iceland since the Laki eruption in 1783-1784 AD, it produced more than $1 \mathrm{~km}^{3}$ of lava, covering $85 \mathrm{~km}^{2}$ area north of Vatnajökull, and released up to $11.2 \mathrm{Mt} \mathrm{SO}_{2}$ into the atmosphere (IMO 2014).

\section{Effects of volcanic tephra}

Volcanic eruptions cause a wide range of hazards, of which tephra is by far the most widespread. Distal impacts over large regions occur due to exposure to tephra, gases, aerosols, and volcanically modified precipitation, and the additional impacts on climate and weather (Lacasse 2001; Self 2006). The scale of influence on the environment and human society can be varied and complicated, due to the nature of the hazard dispersal; the effects are always local, but they can also be regional or even global.

Large explosive eruptions in Iceland have induced significant and long-lasting local impacts, e.g., as shown by the multi-decadal or multi-centennial response of biological proxies after tephra damages the vegetation cover, causing increased soil erosion, increased sedimentation rates, and pronounced landscape destabilization (Larsen et al. 2011, 2012). Tephra-fall can damage vegetation, soil life, and overall ecosystem function. The most drastic tephra events leave behind a barren surface of sterile substrates that require decades or even centuries of natural primary succession to restore (Fridriksson 1981; Thorarinsson 1979).

Tephra can damage vegetation by direct burial, heat, or breakage. Volatiles can adhere to tephra particles and, through dry or wet deposition, can cause lesions, defoliation, or plant death, as seen in the Laki eruption of 1783-1784 (Steingrímsson 1998). Stresses to ecosystems caused by tephra include the inhibition of photosynthesis, changes in the water budget (drought, surface flow, or waterlogging), and changes to predation and disease vulnerability; these may all result in structural changes in the plant community (Antos and Zobel 1985; Cook et al. 1981; Zobel and Antos 1987). Post-eruptive transport of tephra (by water or wind) can be severe (Arnalds et al. 2013), leading to further damage or burial in new areas. Wind erosion with tephra-laden air causes abrasion and desiccation and uncovers plant roots, as well as reducing the soil depth (Hagen and Casada 2013). Tephra in an open landscape can be blown back and forth, becoming a source of dust storms for decades.

Volcanic eruptions can have a wide range of impacts on human health; arguably, these impacts are more varied than for any other kind of natural hazard (Hansell et al. 2006; Horwell and Baxter 2006). Tephra-fall modifies hydrology and lowers air quality, affecting human health both directly, through inhalation or the abrasion of skin and eyes, and indirectly through impacts on terrestrial and aquatic environments (Carlsen et al. 2012; Gudmundsson 2011; Thorsteinsson et al. 2012). Resuspended tephra particles prolong these health hazards. Aerosolization experiments on tephra, using the recent Eyjafjallajökull (2010) and Grímsvötn (2011) eruptions, show the ease of re-dispersal to the air; resuspension also caused a substantial increase in the concentration of respirable airborne ash particles, increasing the potential health hazard (Lähde et al. 2013).

Post-eruptive processes extend the area of influence of a volcanic eruption some distance from the initial deposition area and can last for years. In 2013, 2-3 years after the two 2010-2011 eruptions, resuspension of tephra by wind caused repeated episodes of poor 
air quality, with concentrations up to $1000-6000 \mu \mathrm{g} / \mathrm{m}^{3}$ in Fljótshverfi, S Iceland (50-90 km away from the eruption sites) and up to $100-1100 \mu \mathrm{g} / \mathrm{m}^{3}$ in Reykjavík (140-220 km away), which are well above the recommended limit of $50 \mu \mathrm{g} / \mathrm{m}^{3}$ (EAI 2013). Post-eruptive resuspension of tephra has limited the quality of life in Iceland, as reported in the media as late as 2013 , by causing reduced visibility, ground transportation hazards, property damage (such as sandblasted vehicles), and road closures. Similar effects were seen in Chile after the Mt. Hudson eruption of 1991, where remobilization of ash by wind was observed for at least 10 years after the eruption, causing significant problems in some areas and greatly hindering the re-establishment of agriculture (Bitschene 1995).

Tephra-fall is the only volcanic process that shows a damage gradient. In contrast to lava flows and pyroclastic flows, which cause the total devastation of the affected arable land and vegetation (Bignami et al. 2012), the severity of tephra-fall on agriculture generally increases progressively with tephra thickness, although its effects are linked to those due to social resilience and economic and political factors. In Iceland, tephra-fall has often caused farms to be abandoned. In the lowlands, a tephra thickness of 8-10 cm has led to farm abandonment for a year or less and $15 \mathrm{~cm}$ to abandonment for 1-5 years, while $30-50 \mathrm{~cm}$ of tephra has caused farms to be abandoned for a minimum of decades. In the highlands, a 20-cm-thick tephra-fall caused permanent abandonment (Ágústsdóttir 2013; Thorarinsson 1979). Similar effects on society have been observed in other countries, the key determinant of the re-occupation of farms being recovery of the vegetation (Wilson et al. 2010). Damage to agricultural land or water resources can also have significant impacts on the society's long-term economic growth (Mitchell et al. 2013).

\section{Costs of natural hazards}

The costs to society of even a moderate volcanic eruption can be substantial, as shown by the two Icelandic eruptions of 2010-2011. Both were moderate size events, with VEI indices of 3-4 (Gudmundsson et al. 2012). The prolonged 2010 Eyjafjallajökull eruption (lasting 39 days), combined with persistent NW winds, dispersed low concentrations of fine ash over a large part of Europe. This ash caused an unprecedented, large disruption to air traffic, with the cancelation of 108,000 flights, interrupting the travel of 10.5 million passengers and costing the airline industry in excess of $\$ 1.7$ billion in lost revenue (Eurocontrol 2010). Although there was hardly any direct damage from this eruption, it revealed the vulnerability of modern society's interconnected economies. The consequences of interruptions in supplies of goods to industrial firms worldwide meant that gradually more and more economic sectors were affected by the volcano, in addition to other subsequent negative effects on the global economy.

Comparing this eruption to that, a year later, of Grímsvötn, we can see how the circumstances at the time of an eruption can affect the amount of global economic damage. In 2011, Grímsvötn (at least VEI 4) produced more European tephra fallout in the first $24 \mathrm{~h}$ than occurred during the entire 2010 Eyjafjallajökull eruption, with the bulk volume of tephra 2-3 times greater (Gudmundsson et al. 2012). However, the short duration of the eruption and the absence of strong upper atmospheric winds prevented the dispersal of tephra at the scale observed in 2010 (Marzano et al. 2013); thus, the larger eruption had a lesser effect on global society.

In Iceland, the costs to society of natural hazards are generally high regardless of the circumstances. The effects of tephra-fall, being immediate, long-term, and widespread, 
lead to persistent costs for years afterward. The economic cost of recovery constitutes a major burden on Icelandic society. Tephra-fall and the repeated floods due to the 2010-2011 events led to damages in transportation, agriculture, and tourism. Costs to the Icelandic government for urgent tasks in the affected areas were 11.3 million USD in May 2012 (Prime Minister's Office 2011). Additional costs were covered by the annual budget provisions of various government institutes. Damage to insured property, by the end of 2011, was 3.43 million USD (Viðlagatrygging Íslands 2011). Damage to uninsured property, such as machinery, fields, drainage systems, home power stations, emergency responses, and cleanup, has not been accounted for. Various other indirect and secondary losses, such as social or environmental issues (including damage to ecosystems) and loss of production are unquantifiable in monetary value.

A 2011 European study showed that if DRR initiatives can reduce the cost of damages by less than $1 \%$, then from an economic standpoint such DRR actions can be justified using cost-benefit analyses (European Commission 2011). Cost-benefit analyses are, however, only a decision-making tool. It is rare that all costs and all benefits are assessed and included in a quantitative assessment, while the assessment of risk, the study found, is politicized in all DRR decisions (European Commission 2011). Investing in ecological restoration should be considered, instead, as a high-yielding investment (De Groot et al. 2013). Studies have shown that healthy and resilient ecosystems contribute to climate change adaptation, as well as to disaster risk reduction (CBD 2009; Doswald et al. 2014; Munang et al. 2013; Renaud et al. 2013; World Bank 2010). Investing in preventive measures, including maintaining healthy ecosystems, can be more cost-effective than simply bearing the costs incurred by natural hazards (through inaction) or paying the costs (including construction and maintenance) of engineered solutions to DRR (Jones et al. 2012; PEDRR 2010; UNISDR 2011; World Bank 2010).

\section{Vulnerability of Icelandic ecosystems}

Iceland's climate is humid and cool-to-temperate. Iceland is near the boundary between the midlatitude westerlies and the polar easterlies; cyclones pass frequently, and shifts between frost and thaw are common. The mean annual range of precipitation is $400-2000 \mathrm{~mm}$. The mean annual range of temperature is $2-6^{\circ} \mathrm{C}$, with the mean July range being $6-10{ }^{\circ} \mathrm{C}$ (Einarsson 1976). Cool summers considerably limit the yield and growing potential for a range of plants. The growing season is short, i.e., days above $4{ }^{\circ} \mathrm{C}$ range from 89 to 144 day/year (Fridriksson and Sigurðsson 1983). Natural succession is slow, and revegetation (with minimal human input) generally requires a long recovery time (decades) to turn degraded land into healthy ecosystems.

Iceland's most serious environmental problem is the degraded state of common rangeland in the highlands. Andosols, the main soil type in Iceland, are characterized by a general lack of cohesion (Arnalds 2004) and are vulnerable to degradation and erosion if the vegetation cover is weakened. At the time of settlement, c. $871 \mathrm{AD}, 60 \%$ of Iceland was vegetated and some 25-40\% covered by forest (Arnalds 1987). The current state of Icelandic ecosystems is often far from the expected climax vegetation for the climate. Birch woodland is the natural climax vegetation in Iceland, and lowland areas up to about 300 m.a.s.l. are within the subalpine vegetation zone. Above this limit, and in the outermost coastal districts in the northwest, north, and northeast, arctic-alpine vegetation dominates (Hallsdóttir and Caseldine 2005). At present, after 1100 years of added stress 
from unsustainable land use, about $95 \%$ of the forest has been lost; only $27 \%$ of the country remains vegetated, and natural forests cover $\sim 1.2 \%$ of the total area (Arnalds 1987; Gunnarsson et al. 2005). Surveys show that $40 \%$ of the country is "considerably," "severely," or "extremely" eroded (Arnalds et al. 2001).

\section{Disaster risk reduction and natural hazards}

The risk of volcanic eruptions cannot be avoided in Iceland, as the area of possible impact for the largest events covers the whole island. The Icelanders' only option is to live with the risk and to aim to minimize it through DRR action, lessening the cost society has to bear (Ágústsdóttir 2013; Kelman and Mather 2008). The value of a DRR effort is threefold: in disaster preparedness, quicker recovery, and cost reduction.

By building up healthy ecosystems, DRR increases the resilience of both society and ecosystems to future volcanic events, improving their ability to survive tephra-fall and/or minimizing the disruption (Ágústsdóttir 2013). An ecosystem's resilience to the deposition of tephra depends on several factors: the depth of burial, the species' capability to regenerate when buried, the diversity of responses, seasonality, water availability, and the toxicity of the tephra. Vigorous ecosystems generally have greater endurance and shorter recovery times. Already stressed ecosystems are more vulnerable to the additional stress of tephra-fall. Research on stability domains indicates that efforts to reduce the risk of unwanted state shifts due to disturbances should address the gradual changes that affect resilience, rather than merely controlling the fluctuations caused by the disturbance (Folke et al. 2004; Scheffer et al. 2001). Stability domains, for ecosystems, typically depend on slowly changing processes that affect land use, nutrient stocks, soil properties, and the biomass of long-lived organisms (Scheffer et al. 2001). However, once degraded, ecosystems need human input to reverse these processes and to cross thresholds of energy, nutrients, and the availability of seeds, before it is possible to transition to a more productive state. Such actions have more than a century-long history in Iceland. The methods traditionally used for revegetation in Iceland, i.e., fertilization and/or seeding and planting, are also applicable to emergency revegetation after tephra-fall. DRR strategies that improve the overall health of ecosystems, on the other hand, would be preventive, and the experience gained could aid in planning post-eruptive recovery.

Vegetation is one of the main factors affecting dust emission and dust storm frequency (Engelstaedter et al. 2003; Shinoda et al. 2011; Tegen et al. 2002). Taller vegetation has higher surface roughness, resulting in less dust emission. When visibility data were used to develop a global map of annual dust storm frequency (Engelstaedter et al. 2003), a comparison with vegetation cover revealed an inverse correlation with the leaf area index (an index of vegetation density) and net primary productivity; the highest storm frequency was found in desert/bare ground environments, while a magnitude lower storm frequency occurred in areas with dense vegetation cover. This underscores the importance of vegetation in dust retention.

Vegetation acts as a bioshield reducing wind erosion (Aubault et al. 2015; Breshears et al. 2009; Webb and Strong 2011). The standing biomass modifies the near surface wind profile and alters soil and atmospheric characteristics (soil structure, surface stability, and air moisture). Vegetation controls wind erosion through various processes: (1) by sheltering the ground surface from erosive forces, reducing the friction velocity under the biomass to lower levels at the soil surface, creating wakes of reduced mean wind velocity, 
and covering a portion of the ground, thereby limiting the erodible area; (2) through momentum extraction from the wind, by absorbing a part of the total shear stress of the wind and thereby decreasing the shear stress acting on the ground and on the downstream plants; and (3) by trapping and intercepting windborne particles to further reduce their transport capacity (Hagen and Casada 2013; Shao 2000; Wolfe and Nickling 1993). Stronger winds are required to initiate erosion in vegetated areas. The threshold velocities required to initiate the saltation effect of wind erosion generally increase with both leaf area index and canopy height (Hagen and Casada 2013). Standing biomass reduces the surface loss from abrasion by the saltating sand grains an average of $35 \%$ (Hagen and Casada 2013).

Land cover in Iceland is characterized by seminatural surfaces $(95.2 \%)$, while agriculture areas cover only $2.4 \%$, according to the Corine land classification system (National Land Survey of Iceland 2009). Plowing to remove tephra is only possible on a very limited part of these agricultural areas. Removal of tephra and recovery of an ecosystem thus depend mainly on natural processes. Recovery via extant vegetation and recolonization will likely play a role in the post-eruptive natural revegetation and succession processes. Efficient post-event buildup of ecosystems depends on natural regeneration ability of the site, through species, microsite, and successional patterns (Titus and Tsuyuzaki 2003). Tephra-induced changes exert strong selective pressures, by filtering intolerant species out of the community (Maun 2004). A species' response to disturbance is typically classified into three processes: tolerance, avoidance, and regeneration (Burylo et al. 2012; Lavorel and Garnier 2002). Tolerance to tephra-fall is very dependent on the vegetation's height, as partial burial is easier to withstand than complete burial (Burylo et al. 2012). Experience from volcanoes in Japan shows that a species' survival following an eruption occurs either via a seed bank or through vegetative recovery, provided that disturbance gradients such as the thickness of the tephra-fall and/or the ground surface stability do not exceed the species' tolerance (Tsuyuzaki 2009; Tsuyuzaki and Hase 2005). Post-eruptive erosion can also be beneficial if buried plants are uncovered in time to aid in the recovery.

Healthy ecosystems bounce back more quickly after tephra-fall. Surface stabilization is achieved, as the tephra is removed into the soil more quickly via root action and by adding new organic material onto the surface. Surviving vegetation provides a local source of seeds, while the shelter provided by vegetation both living and dead reduces secondary transport. In areas with little or no vegetation, on the other hand, the fallen tephra is unstable and easily moved repeatedly by erosion, causing further abrasive damage. This effect was clearly observed in S Iceland after the recent eruptions. Research on the Hekla eruption of $1104 \mathrm{AD}$ indicates a rapid surface stabilization of areas with deep vegetation cover, due to the vegetation subsequently growing through $35 \mathrm{~cm}$ of tephra. Other areas, by contrast, were affected by erosion cutting into the underlying sediments and experienced prolonged phases of instability, with discrete episodes of surface transport; such processes continued until 1300 AD (Dugmore et al. 2007). History thus suggests that DRR actions to produce healthy ecosystems can lessen post-eruptive tephra transport, producing fewer incidents of low air quality, less disruption, and reduced cleanup, resulting in less cost to society and better human and ecosystem health.

The degraded common rangelands in the highlands of Iceland are especially vulnerable to tephra-fall events. Eroded surfaces like these, which are barren or have a partial vegetation cover of sparse and low-growing plants, are easily disrupted. The resilience of this rangeland to catastrophic events can be drastically improved by reclamation efforts, as well as by reducing the grazing intensity. Diminished dependence on land use in certain 
high-risk areas would lower the country-wide risk of societal disturbance by tephra-fall events. Improved overall ecosystem status could also provide future options for changed post-eruptive land use, initiated as emergency short-term solutions or as a permanent landuse change. Risk reduction actions have additional positive spin-offs, including decreased erosion, increased soil fertility and water-holding capacity, and preservation or enhancement of carbon stocks, biodiversity, and wildlife habitat, providing health and recreational benefits.

\section{Effective governance and policies}

Land-use practices affect ecological processes in several vital ways, causing changes to the composition, structure, and function of ecosystems. Environmental laws and agricultural incentives both influence land use, but policy changes or new incentives are often needed to implement management practices aiming for long-term environmental goals. Effective governance of DRR requires an alignment of policies, including those pertaining to agriculture, land-use planning/zoning, natural resource management, climate change mitigation through revegetation, and restoration of native forests. Coherent legislation, cross-sector integration, and effective knowledge sharing are all needed to make ecosystem-based DRR approaches successful and to maximize their potential benefits. In Iceland, the following policies need to be taken into consideration when designing DRR approaches to tephra-fall.

\subsection{Agricultural policies}

Agricultural areas in Iceland are mainly in the lowlands, below 200 m.a.s.l., and cover $<1.2 \%$ of the country's total land area, whereas potentially they could cover an estimated $<6 \%$ (Snæbjörnsson et al. 2010). Traditional agriculture is based on rangeland grazing and on haymaking for indoor feeding during winter.

Agricultural subsidies have put pressure on Iceland's ecosystems. From the 1950s to the early 1980s, subsidies rewarded production, leading to an increased number of sheep until production limitation quotas were set in 1978 and revised in 1985. Positive changes were brought about through the work of the Soil Conservation Service of Iceland, which has battled land degradation since 1907 (Olgeirsson 2007). In recent decades, two voluntary land restoration incentive programs, "The Farmers Heal the Land" (since 1990) and "The Land Improvement Fund" (since 2003), have led to farmland improvement, moving the initiative and responsibility from the state to the local authorities and land users. A policy change in 2000 encouraged sustainability, as the Icelandic government signed a contract with sheep farmers on partial cross-compliance agricultural support. Participation is voluntary; farmers meeting the land-use quality criteria get up to $22.5 \%$ more in subsidies. Under this program, grazing should be sustainable on land in acceptable condition. However, from an environmental perspective, the criteria are not stringent enough, and continued land use is allowed if improvement plans are made. Furthermore, the definition of "sustainable land use" is not scientific, but instead based on criteria agreed upon between the sheep farmers and the government. Sanctions against overexploitation are limited. Laws to control grazing on degraded land exist in theory (for example, Act. $6 / 1986,17 / 1964)$, but in practice any attempts to enforce them have not led to real grazing control. 
A global comparison of case studies suggests that, in seven out of eight cases, the economic consequences of land degradation are much higher than the costs of related inaction, even when the costs of degradation are defined only in terms of decreased crop yields (Nkonya et al. 2011). Reasons for failing to take action against land degradation are often based on policy (Braun et al. 2012). Improved land health and the improved economy of rural areas could be obtained if agricultural policies had less emphasis on production and more of a focus on environmental values. This finding is in line with a recent synthesis by OECD (2010) on the linkage of agriculture policy and rural development, suggesting that, faced with heterogeneity in rural areas, the continued shift from a sectoral emphasis toward place-based policies is likely to lead to increasingly effective policies.

\subsection{Land-use planning and wilderness protection in the central highlands}

Iceland's interior highlands are uninhabited, yet they are influenced by land-use planning and socioeconomic pressures. They are important as common grazing areas for lowland sheep-farming communities. Each municipality manages its adjacent areas, which extend toward the center of the country. Legislation passed in 1998 (Act. 58/1998) to clarify the ownership of the highlands provided a legal basis for the Icelandic state to own both the land and the land rights that are not subject to private ownership. This act led to an ongoing legal procedure disputing private and governmental claims. Stakeholders are diverse, with conflicting economic interests. Farmers, landowners, municipalities, power companies, various types of tourism, recreational users, and nature conservationists all have divergent visions of nature and land use. New legislation on planning (Act 123 of 2010) is intended to provide a coordination platform for sectoral plans regarding these central highlands. Land-use intensification generally leads to reduction in both response diversity and functional redundancy, thereby reducing an ecosystem's resilience to future disturbances (Laliberte et al. 2010). Successful resource management should aid in ecosystem buildup, not add to the chronic stress that makes the effects of the disturbances permanent (Mori et al. 2013).

\subsection{Rural policies}

Rural development often involves areas with declining income, declining employment, and a falling population; it is concerned with stimulating economic growth, creating new sources of income, and preventing the further decline of rural populations (OECD 2009). Iceland is no exception: More than half of the population lives in the city of Reykjavík, after persistent urbanization and depopulation of rural areas during the last century. About $7 \%$ of the nation lives in areas with small local population clusters, where diverse employment and services cannot be maintained (Bjarnason 2010). Remote marginal lands face the possibility of being withdrawn from production; they experience high transport costs and are only marginally profitable. They are also more likely to be linked with adverse environmental effects, such as erosion due to mismanagement. Agriculture and rural development in these sites could benefit from a diversification of policies.

\subsection{Climate change mitigation through revegetation}

Increasing carbon sequestration in the soil and in vegetation through reclamation of degraded or desertified land is an important part of Iceland's climate change actions for the 
UNFCCC (Art. 3.4 of the Kyoto Protocol). In Iceland, revegetation on 83.21 kha removed $167 \mathrm{Gg} \mathrm{CO}_{2}$ eq. (Net-Net accounting) in 2010, compared to 1990 (Environment Agency of Iceland 2012). Revegetation is also a part of ten major tasks of an Icelandic governmental action plan from 2010 to curb greenhouse gas emissions. This strategy aims for a 50-75\% overall reduction by 2050, compared to 1990, yet the trend from 1990 to 2010 suggests a $30 \%$ increase in these emissions (Environment Agency of Iceland 2012). The effectiveness of this policy goes hand in hand with the funding provided: Since 2003, funds to the Soil Conservation Service of Iceland have decreased by $30 \%$. To reach the emission reduction target, more effort should be put into the removal of carbon through revegetation. Early action accumulates more carbon with more climate benefits.

\section{Reclaiming vulnerable land and building healthy ecosystems}

National strategies for the restoration of native Icelandic woodlands, set forth in 2007, aim to increase forest cover to $10 \%$ of the island in the future (Ministry for the Environment 2007). Various projects contribute to this effort, such as revegetation by the Soil Conservation Service of Iceland and regional afforestation programs. Birch (Betula pubescens) has been the only forest-forming tree species in Iceland since the Holocene. Birch and willow species (Salix spp.) have good potential for natural regeneration, often being early colonizers in natural succession and key species in ecosystem development. On severely degraded land, land reclamation is often necessary prior to afforestation to stabilize the surface, halt soil erosion, restore ecosystem functioning, and provide sites for seeds.

Restoration strategies for Iceland's native forests are well presented in the Hekluskógar project (Hekluskógar 2015). This $900 \mathrm{~km}^{2}$ woodland restoration of native birch and willows near Hekla volcano, S Iceland, aims to reduce the potential damage from future Hekla eruptions by increasing ecosystem resilience and limiting the secondary distribution of tephra to nearby regions. When the project began in 2005, Hekluskógar was mostly comprised of desertified land at a fairly low elevation. Forest remnants, historical accounts, and place names, however, suggested that forests had grown there in the past which, in the post-settlement period, were degraded over time as human land use and tephra-fall events led to severe erosion.

Ecosystem functioning in Hekluskógar now remains hampered by nutrient-limited soil, low water-holding capacity, unstable surfaces, and extensive frost heaving, which together limit its natural recovery and the establishment of seedlings. Revegetation through fertilization and seeding helps to overcome these ecological thresholds, stimulating a natural succession of local flora and aiding ecosystem development. The extent of the area and the input needed, however, place practical limits on this otherwise very successful woodland restoration attempt. Self-seeding is promoted by strategic placement of tree seedlings, which in the future will act as sources for seed dispersal and further colonization by winddispersed species.

The success of the startup at Hekluskógar is credited to the fact that planning and management is a joint effort of various stakeholders: landowners, governmental officials, scientists, and extension officers. It represents an alignment of policies toward a united goal of sustainability and DRR. A similar buy-in by all stakeholders will be necessary to expand the Hekluskógar concept to areas near other active Icelandic volcanoes. This expansion will first, however, require a determination of which areas will see most benefit from the Hekluskógar approach; such areas may not be those that are most at risk from a 
tephra-fall event. Predictions of volcanic impact zones are in general a difficult task that often constrains DRR action (Bignami et al. 2012), since in Iceland, as stated above, the whole island can endure damage in the largest eruptions. Areas of influence for smaller to medium eruptions, however, are usually regional, with a directional extent. In these regional focus areas, a new risk assessment for volcanic hazards, currently in progress, will provide the information needed to plan a more detailed, long-term DRR action.

Identifying high-risk zones, based either on the expected frequency of volcanic eruptions or on their degree of impact, can aid in directing DRR actions, as well as improving their ease of execution and increasing their expected social value. Areas that face multiple natural hazard risks (e.g., of different frequency or magnitude, as well as possibly interacting risks) could arrive at effective multi-risk approaches through a cost/benefit analysis of DRR actions. Actions such as those represented by the Hekluskógar project are likely to be most successful outside of the zone of extreme impacts, from areas of medium impact toward the edge of the impact zone. In zones where extreme impacts are likely, any preventive DRR action is likely to have limited value. There, only post-eruptive revegetation can stimulate natural succession on fresh volcanic deposits.

Preliminary results, based on the location of Iceland's most active volcanoes, the frequency of tephra layers in the soil (Larsen and Gíslason 2013), and the prevailing wind patterns (Jónsson 1990, 2010), suggest that areas in S and SE Iceland are the most likely to experience tephra-fall events (Fig. 1).This region of expected tephra-fall, stretching $270 \mathrm{~km}$ along the southeast coast, is also considered "fragile" in the sense of rural development, with negative trends regarding population, age structure, and employment (Bjarnason 2010). The population in this area has fallen by $13 \%$ during the last decade (Bjarnason 2010). Cultural and behavioral barriers have to be addressed. Rural communities in S and SE Iceland, for instance, may be unwilling to change their traditional landuse patterns and thereby affect rural cultural events, such as the autumn sheep gathering from communal areas. There may also be uncertainty about whether property rights based on tradition will be lost, if this type of land use is discontinued. Information could overcome these barriers, so that resistance to change does not limit progress toward sustainable land use. Changes through regulatory governance and involving local stakeholders can guide these rural communities toward a more sustainable use of natural resources.

Natural systems have large absorption capacities; yet once tipping points are reached, they can suddenly crash, with devastating consequences for other economic and social systems (United Nations ESCAP 2013). Ecosystems at risk should receive priority for management interventions to enhance their resilience or restore the desired stability domain. Building resilience will mean addressing a nexus of converging threats. One key is to understand how land use exacerbates episodic disturbances that can reshape systems. Effective land-use planning can be applied as DRR, diminishing existing stress by building up healthy ecosystems, thereby enhancing the ecosystems' resilience and reducing societal vulnerability to natural hazards (EEA 2010). Land-use planning does, however, have unresolved challenges. Few disaster risk management systems have been able to employ land-use planning or to influence investment policies to encourage effective disaster risk management (Johnson 2011; UNISDR 2011).

Planning for recovery after a disaster is likewise missing in most countries, with a few exceptions such as China, Canada, and New Zealand, where disaster recovery is linked to broader projects of governance (Mitchell 2006). Iceland could benefit from forming a recovery plan for ecosystems that have endured tephra-fall, following New Zealand's example of making sustainability the guiding principle of all public actions taken during the recovery phase of disasters (Mitchell 2006). 
The state of an ecosystem determines its tolerance to disturbances and affects its recovery time (Grandy et al. 2012; Lindig-Cisneros et al. 2006). The extensive ecosystem degradation in Iceland, coupled with the island's short growing season, ensures that posteruptive ecosystem recovery is a long-term process. A preventive DRR approach through healthier ecosystems, combined with a post-event approach of planning for sustainability, could speed up this recovery. Positive tipping points may occur in the recovery process, when human interventions in degraded ecosystems allow their processes and populations to recover (Olgeirsson 2007; Westley et al. 2011). Ecosystem functioning and the traits that lead to enhanced ecosystem resilience and succession in Iceland need to be explored while planning this ecosystem recovery process. It is within this context that the Hekluskógar concept is most successful. With its effective stakeholder participation, alignment of policies, use of local flora, and heterogeneous solutions tailored to fit the local environment, the concept can be transferred to other regions that are likely to be at risk of tephrafall.

\section{Conclusions}

As volcanic activity in Iceland is expected to rise in the future, increased natural hazard risks can be anticipated. Eruptions in 2010-2011 proved the value of pre-disaster planning for some volcanic hazards, but a new focus is needed on pre-disaster mitigation responses for the effects of tephra-fall on vegetation. As outlined in the UNISDR Hyogo Framework, healthy ecosystems and environmental management are key actions in disaster risk reduction (DRR). The Hyogo Framework further recommends that policymakers take six steps toward DRR: assessment, prevention, mitigation, monitoring, early warning, and preparedness (UN-ISDR 2013). The assessment here of the tephra-fall problem has shown that vulnerability exists due to current land use in Iceland and that the underlying risk factors could be reduced. Prevention of tephra-fall events is impossible, but improved ecosystem health could prevent further degradation and move systems away from negative ecosystem tipping points (Sidle et al. 2013). Mitigation has been shown to improve ecosystem resilience. Monitoring improves knowledge on ecosystem status, detects subtle signs of resilience loss (Sidle et al. 2013), and suggests improvements. Such monitoring is important to set up in Iceland. Early warning immediately prior to events is irrelevant here, as ecosystem processes operate on long-time scales. Preparedness can be obtained from studying past events and through sustainable practices. Societal DRR benefits will include the economic and human health benefits of healthy ecosystems and their services prior to an eruption, while, afterward, those ecosystems that survive tephra-fall will reduce the secondary transport of tephra. Post-eruptive benefits to society will be faster recovery for the economy, transport, and agriculture, and, first and foremost, better air quality.

The Hyogo Framework is due to expire in 2015, and a wide consultation process is currently shaping its successor, the post-2015 framework for disaster risk reduction. The new Sendai DRR framework was endorsed at the Third UN World Conference for Disaster Risk Reduction in Sendai, Japan on March 14-18, 2015 (UNISDR 2015). At its core are four priorities for action: (1) understanding disaster risk, (2) strengthening disaster risk governance to manage disaster risk, (3) investing in disaster risk reduction for resilience, and 4) enhancing disaster preparedness for effective response and to "Build Back Better" in recovery, rehabilitation, and reconstruction. These priorities are directly aligned with our approach here: (1) we have strengthened the evidence base for an ecosystem approach to 
DRR for volcanic tephra-fall; (2) we have pointed out governance issues in Iceland that need to be strengthened for effective DRR; (3) we have suggested an alignment of various policies regarding land-use, land degradation, and rural development in order to strengthen the sustainable land-use management of ecosystems and form an integrated natural resource management approach that incorporates DRR; and (4) we have suggested that heightened ecosystem resilience is the key to disaster preparedness and to efficient recovery.

Vulnerability to tephra-fall is dynamic, changing in both space and time, and depends on a complex relationship between nature and society. Societal changes in governance, the understanding of hazards, technology, coping mechanisms (before, during, and after), and the resources available to DRR or post-event response actions all fluctuate over time. Consider, for instance, the difference in vulnerability between the pre-industrial subsistence farming community, where the effects of major eruptions could lead to nationwide crisis, depression, and famine (Thordarson and Self 2003), and the modern society that can follow online the real-time measurements of activity during an ongoing volcanic eruption. All communities need the skills, capacity, and experience to cope and adapt. Among these, an awareness of risk and vulnerability can enable informed decision making. We have linked here volcanic eruptions to ecosystem-based disaster risk reduction and the need for sustainable land-use management, although the use of ecosystems as "bioshields" is not a panacea and should be accompanied by other measures, e.g., early warning systems, disaster preparedness, and emergency actions, to decrease people's vulnerability to natural hazards (Feagin et al. 2010). However, if Iceland's currently unsustainable land-use practices are continued, the country's vulnerability to tephra-fall will increase; the minimum benefit of DRR would be to limit that increase in vulnerability. Alternately, a weak framework of legislation and policy, poor land-use planning, and inertia to change are some of the economic, political, scientific, and social components contributing the most to environmental degradation.

Ecosystem services are essential for sustainable livelihoods, both immediately and in the long term. The restored habitats of an ecosystem-based DRR effort will improve the capacity of both ecosystems and people to withstand future extreme natural hazards. Investments in sustainable land management can offer cost-effective solutions (De Groot et al. 2013) to reducing a community's vulnerability to natural hazards such as volcanic eruptions. It costs less (in economic, social, and political terms) to prevent or mitigate hazards than it does to clean up and fund recovery after a disaster (Anderson 1990). Ecosystem-based DRR in Iceland could also merge the goals of sustainable and rural development. Combining ecosystem restoration in degraded areas with long-term views of rural development, nature protection, agriculture, and resource management leads to a proactive, cost-effective alternative to the reactive, emergency-response expenses, while pooling limited resources for rural, agriculture, and ecological development provides more leverage toward sustainability and resilience. In the long term, DRR investments have a high rate of return and contribute to sustainable economic development (European Commission 2013). But investing in prevention, versus only reacting to disasters, requires political will, resources, and an adherence to long-term political strategies that recognize the value of ecosystems and the need for DRR solutions.

The key messages presented in this article are not only relevant for DRR in Iceland but are also valid for other regions, especially in other volcanic areas where people depend strongly on natural resources, where environmental conditions are degraded, and where the growth of vegetation is limited by harsh environmental conditions. The innovative approach suggested here aims to reduce environmental vulnerabilities in order to reduce the 
primary and secondary effects of volcanic tephra on ecosystems and human health. The opportunities that effective ecosystem management provides for DRR, in terms of decreasing the vulnerability of both people and ecosystems to future extreme events, should be given high priority in disaster management planning. Encouraging the sustainable use and appropriate management of fragile ecosystems now has an additional aim: to reduce risk and vulnerabilities to natural hazards.

Acknowledgments I thank Nancy Marie Brown, Magnús H. Jóhannsson (SCSI), Arna Björk Porsteinsdóttir (SCSI), Guðmundur Halldórsson (SCSI), and anonymous reviewers for their help in improving the manuscript.

Open Access This article is distributed under the terms of the Creative Commons Attribution 4.0 International License (http://creativecommons.org/licenses/by/4.0/), which permits unrestricted use, distribution, and reproduction in any medium, provided you give appropriate credit to the original author(s) and the source, provide a link to the Creative Commons license, and indicate if changes were made.

\section{References}

Ágústsdóttir AM (2013) Gróður og eldgosavá. Forvarnagildi gróðurs gegn hamförum af völdum eldgosa og eldfjallagjósku. Skýrsla til nefndar um gerð hættumats vegna eldvirkni. [Vegetation and volcanic eruptions. Ecosystem- based Disaster Risk Reduction (Eco-DRR). Report for risk assessment regarding volcanic eruptions in Iceland] Rit Landgræðslu ríkisins nr 1/2013 1:66

Alley RB (2000) The two-mile time machine: ice cores, abrupt climate change, and our future. Princeton University Press, Princeton

Anderson M (1990) Analyzing the costs and benefits of natural disaster responses in the context of development. Environment Working Paper 29, World Bank, Washington

Antos JA, Zobel DB (1985) Recovery of forest understories buried by tephra from Mount St. Helens. Vegetatio 64:103-111

Arnalds A (1987) Ecosystem disturbance in Iceland. Arct Alp Res 19:508-513. doi:10.2307/1551417

Arnalds O (2004) Volcanic soils of Iceland. Catena 56:3-20. doi:10.1016/j.catena.2003.10.002

Arnalds O, Thórarinsdóttir EF, Metúsalemsson S, Jónsson Á, Grétarsson E, Árnason A (2001) Soil erosion in Iceland. Soil Conservation Service, Agriculture Research Institute, Reykjavík English translation, originally published in Icelandic (1997)

Arnalds O, Thorarinsdottir EF, Thorsson J, Waldhauserova PD, Agustsdottir AM (2013) An extreme wind erosion event of the fresh Eyjafjallajokull 2010 volcanic ash. Sci Rep 3:7. doi:10.1038/srep01257

Aubault H, Webb NP, Strong CL, McTainsh GH, Leys JF, Scanlan JC (2015) Grazing impacts on the susceptibility of rangelands to wind erosion: the effects of stocking rate, stocking strategy and land condition. Aeolian Res 17:89-99. doi:10.1016/j.aeolia.2014.12.005

Bignami C, Bosi V, Costantini L, Cristiani C, Lavigne F, Thierry P (2012) Handbook for volcanic risk management: prevention, crisis management, resilience. MIAVITA Project-European Commission under the 7th Framework Programme for Research and Technological Development, Orleans

Birkmann J et al (2008) Extreme events and disasters: a window of opportunity for change? Analysis of organizational, institutional and political changes, formal and informal responses after mega-disasters. Nat Hazards 55:637-655

Birkmann J et al (2013) Framing vulnerability, risk and societal responses: the MOVE framework. Nat Hazards 67:193-211. doi:10.1007/s11069-013-0558-5

Bitschene P (1995) Environmental impact and hazard assessment of the August 1991 eruption of Mt. Hudson (Patagonian Andes). In: Bitschene P, Mendia J (eds) The August 1991 eruption of the Hudson volcano (Patagonian Andes): a thousand days after. Cuvillier Verlag, Universidad Nacional de la Patagonia San Juan Bosco, Göttingen, pp 2-15

Bjarnason T (2010) Demographics, transportation and settlement development. Part of the 2020-moving Iceland forward initiative November 2010. The Prime Minister's Office, University of Akureyri. http:// www.forsaetisraduneyti.is/verkefni/soknaraaetlun-2020/landshlutar/mannfjoldi/. 2013

Boyd WE, Lentfer CJ, Parr J (2005) Interactions between human activity, volcanic eruptions and vegetation during the Holocene at Garua and Numundo, West New Britain. PNG Quat Res 64:384-398 
Braun J, Gerber N, Mirzabaev A, Nkonya E (2012) The Economics of land degradation. An issue paper for global soil week, Berlin 18-22 Nov 2012. Center for Development Research (ZEF), University of Bonn, International Food Policy Research Institute (IFPRI), Washington and Berlin

Breshears DD, Whicker JJ, Zou CB, Field JP, Allen CD (2009) A conceptual framework for dryland aeolian sediment transport along the grassland-forest continuum: Effects of woody plant canopy cover and disturbance. Geomorphology 105:28-38. doi:10.1016/j.geomorph.2007.12.018

Burylo M, Rey F, Dutoit T (2012) Responses of five woody species to burial by marly sediment: the role of biomass allocation pattern flexibility J. Plant Ecol 5:287-293. doi:10.1093/jpe/rtr030

Carey RJ, Houghton BF, Thordarson T (2010) Tephra dispersal and eruption dynamics of wet and dry phases of the 1875 eruption of Askja Volcano. Iceland Bull Volcanol 72:259-278

Carlsen HK et al (2012) Health effects following the Eyjafjallajökull volcanic eruption: a cohort study. BMJ Open 2. doi:10.1136/bmjopen-2012-001851

CBD (2009) Connecting biodiversity and climate change mitigation and adaptation: report of the second ad hoc technical expert group on biodiversity and climate change. Technical series no. 41. Secretariat of the Convention on Biological Diversity, Montreal

Cook R, Barron J, Papendick R, Williams GI (1981) Impact on agriculture of the Mount St. Helens eruptions. Science 211:16-22

Costanza R (1992) Toward an operational definition of ecosystem health. In: Costanza R, Norton B, Haskell BJ (eds) Ecosystem health: New goals for environmental management. Island Press, Washington, pp 239-256

Costanza R (2012) Ecosystem health and ecological engineering. Ecol Eng 45:24-29. doi:10.1016/j.ecoleng. 2012.03.023

De Groot RS, Blignaut J, van der Ploeg S, Aronson J, Elmqvist T, Farley J (2013) Benefits of investing in ecosystem restoration. Conserv Biol 27:1286-1293. doi:10.1111/cobi.12158

Doswald $\mathrm{N}$ et al (2014) Effectiveness of ecosystem-based approaches for adaptation: review of the evidence-base. Clim Dev 6:185-201. doi:10.1080/17565529.2013.867247

Dugmore AJ, Church MJ, Mairs K-A, McGovern TH, Perdikaris S, Vésteinsson O (2007) Abandoned farms, volcanic impacts, and Woodland management: revisiting Pjórsárdalur, the "Pompeii Of Iceland". Arct Anthropol 44:1-11. doi:10.3368/aa.44.1.1

EAI (2013) Measurements of air quality by the Environment Agency of Iceland. Umhverfisstofnun Íslands. http://www.ust.is/einstaklingar/loftgaedi/maelingar/. Accessed 20. March 2013

EEA (2010) Mapping the impacts of natural hazards and technological accidents in Europe-an overview of the last decade. EEA, Copenhagen. doi:10.2800/62638

Einarsson MÁ (1976) Climate of Iceland. Iðunn, Reykjavík, In Icelandic (Veðurfar á Íslandi)

Eliasson J, Larsen G, Gudmundsson MT, Sigmundsson F (2006) Probabilistic model for eruptions and associated flood events in the Katla caldera. Iceland Comput Geosci 10:179-200. doi:10.1007/s10596005-9018-y

El-Masri S, Tipple G (2002) Natural disaster. Mitigation and sustainability: The case of developing countries. Int Plan Stud 7:157-175. doi:10.1080/1356347022013223

Engelstaedter S, Kohfeld KE, Tegen I, Harrison SP (2003) Controls of dust emissions by vegetation and topographic depressions: an evaluation using dust storm frequency data. Geophys Res Lett 30:4. doi:10.1029/2002GL016471

Environment Agency of Iceland (2012) Emissions of greenhouse gases in Iceland from 1990 to 2010. National Inventory Report 2012. Submitted under the United Nations Framework Convention on Climate Change and the Kyoto Protocol. Environment Agency of Iceland, Reykjavík

Eurocontrol (2010) Ash-cloud of April and May 2010: Impact on Air Traffic STATFOR/Doc394. Eurocontrol, Brussels

European Commission (2011) Study on the impacts of the developments of certain aspects of EU disaster risk management. Final report. European Commission, Directorate-General for Humanitarian Aid and Civil Protection (ECHO), Strasbourg

European Commission (2013) Green paper on the insurance of natural and man-made disasters vol COM(2013) 213 final European Commission, Strasbourg

Feagin RA et al (2010) Shelter from the storm? Use and misuse of coastal vegetation bioshields for managing natural disasters. Conserv Lett 3:1-11. doi:10.1111/j.1755-263X.2009.00087.x

Folke C, Carpenter S, Walker B, Scheffer M, Elmqvist T, Gunderson L, Holling CS (2004) Regime shifts, resilience, and biodiversity in ecosystem management. Annu Rev Ecol Evol Syst 35:557-581. doi:10. 1146/annurev.ecolsys.35.021103.105711

Fridriksson S (1981) Effect of tephra on vegetation. (In Icelandic: Áhrif gjósku á gróđur) Ráđunautafundur 1981 2:174-177 
Fridriksson S, Sigurðsson FH (1983) The effect of air-temperature on grass growth (In icelandic: Áhrif lofthita á grassprettu). J Icel Agric Res 15:41-54

Grandy S, Fraterrigo JM, Billings SA (2012) Soil ecosystem resilience and recovery. In: Wall DH et al (eds) Soil ecology and ecosystem services. Oxford University Press, Oxford. doi:10.1093/acprof:oso/ 9780199575923.003 .0031

Gudmundsson G (2011) Respiratory health effects of volcanic ash with special reference to Iceland. A review. Clin Respir J 5:2-9

Gudmundsson MT, Larsen G, Höskuldsson Á, Gylfason ÁG (2008) Volcanic hazards in Iceland. Jokull 58:251-268

Gudmundsson MT et al (2012) Ash generation and distribution from the April-May 2010 eruption of Eyjafjallajökull. Iceland Sci Rep. doi:10.1038/srep00572

Gudmundsson A, Lecoeur N et al (2014) Dike emplacement at Bardarbunga, Iceland, induces unusual stress changes, caldera deformation, and earthquakes. Bull Volcanol 76(10):7

Gunnarsson KS, Eysteinsson T, Curl SL, Thorfinnssont T (2005) Forest Sector Entrepreneurship in Europe: Country Studies. Iceland Acta Silvatica et Lignaria Hungarica Spec Ed 2005:335-346

Haflidason H, Eiriksson J, Kreveld SV (2000) The tephrochronology of Iceland and the North Atlantic region during the middle and late quaternary: a review. J Quat Sci 15:3-22

Hagen LJ, Casada ME (2013) Effect of canopy leaf distribution on sand transport and abrasion energy. Aeolian Res 10:37-42. doi:10.1016/j.aeolia.2013.01.005

Hallsdóttir M, Caseldine CJ (2005) The Holocene vegetation history of Iceland, state of the art and future research. In: Caseldine C, Russel A, Harðardóttir J, Knudsen Ó (eds) Iceland-modern processes and past environments. Developments in quaternary science. Elsevier, Amsterdam, pp 319-334. doi:10. 1016/S1571-0866(05)80016-8

Hansell AL, Horwell CJ, Oppenheimer C (2006) The health hazards of volcanoes and geothermal areas. Occup Environ Med 63:149-156. doi:10.1136/oem.2005.022459

Hekluskógar (2015) The Mt. Hekla afforestation project. Hekluskógar. http://hekluskogar.is/. Accessed 2015

Hodell DA, Curtis JH, Brenner M (1995) Possible role of climate in the collapse of Classic Maya civilization. Nature 375:391-394

Horwell CJ, Baxter PJ (2006) The respiratory health hazards of volcanic ash: a review for volcanic risk mitigation. Bull Volcanol 69:1-24. doi:10.1007/s00445-006-0052-y

IMO (2011) Hættumat fyrir eldgos. The Icelandic Meteorological Office. http://www.vedur.is/um-vi/frettir/ nr/2278. Accessed 31 Aug 2012

IMO (2014) 100 days of continuous eruptive activity in Holuhraun. Icelandic Met Office. http://en.vedur.is/ media/jar/bb100days_ens.pdf

Johnson C (2011) Creating an enabling environment for reducing disaster risk: recent experience of regulatory frameworks for land, planning and building in low and middle-income countries., Background paper prepared for the, 2011. Global assessment report on disaster risk reductionUNISDR, Geneva

Jones HP, Hole DG, Zavaleta ES (2012) Harnessing nature to help people adapt to climate change. Nat Clim Change 2:504-509. doi:10.1038/nclimate1463

Jónsson T (1990) Hvert liggja gjóskugeirar? Nátt 60:103-105

Jónsson T (2010) Hvert berst gosaska? Veðurstofa Ísland/Icelandic Met Office. http://www.vedur.is/vedur/ frodleikur/greinar/nr/1866

Kelman I, Mather TA (2008) Living with volcanoes: the sustainable livelihoods approach for volcanorelated opportunities. J Volcanol Geotherm Res 172:189-198. doi:10.1016/j.jvolgeores.2007.12.007

Lacasse C (2001) Influence of climate variability on the atmospheric transport of Icelandic tephra in the subpolar North Atlantic. Glob Planet Change 29:31-55. doi:10.1016/s0921-8181(01)00099-6

Lähde A et al (2013) In vitro evaluation of pulmonary deposition of airborne volcanic ash. Atmos Environ 70:18-27. doi:10.1016/j.atmosenv.2012.12.048

Laliberte $\mathrm{E}$ et al (2010) Land-use intensification reduces functional redundancy and response diversity in plant communities. Ecol Lett 13:76-86. doi:10.1111/j.1461-0248.2009.01403.x

Larsen G (2000) Holocene eruptions within the Katla volcanic system, south Iceland: Characteristics and environmental impact. Jokull 49:1-28

Larsen G, Gíslason SR (2013) Gjóska. In: Sólnes J, Sigmundsson F, Bessason B (eds) Náttúruvá á ÍslandiEldgos og jarðskjálftar. Viðlagatrygging Íslands/Háskólaútgáfan, Reykjavík, pp 130-143

Larsen G, Gudmundsson MT, Björnsson H (1998) Eight centuries of periodic volcanism at the centre of the Icelandic hotspot revealed by glacier tephrostratigraphy. Geology 26:943-946

Larsen DJ, Miller GH, Geirsdottir A, Thordarson T (2011) A 3000-year varved record of glacier activity and climate change from the proglacial lake Hvitarvatn. Iceland Quat Sci Rev 30:2715-2731. doi:10.1016/ j.quascirev.2011.05.026 
Larsen DJ, Miller GH, Geirsdottir A, Olafsdottir S (2012) Non-linear Holocene climate evolution in the North Atlantic: a high-resolution, multi-proxy record of glacier activity and environmental change from Hvitarvatn, central Iceland. Quat Sci Rev 39:14-25. doi:10.1016/j.quascirev.2012.02.006

Lavorel S, Garnier E (2002) Predicting changes in community composition and ecosystem functioning from plant traits: revisiting the Holy Grail. Funct Ecol 16:545-556. doi:10.1046/j.1365-2435.2002.00664.x

Lindig-Cisneros R, Galindo-Vallejo S, Lara-Cabrera S (2006) Vegetation of tephra deposits 50 years after the end of the eruption of the Paricutin Volcano, Mexico. Southwest Nat 51:455-461. doi:10.1894/ 0038-4909(2006)51[455:votdya]2.0.co;2

Map Viewer, IS 50 V (2013) National land survey of Iceland (Landmælingar Íslands). http://atlas.lmi.is/ is $50 \mathrm{v} /$

Marzano FS, Lamantea M, Montopoli M, Herzog M, Graf H, Cimini D (2013) Microwave remote sensing of the 2011 Plinian eruption of the Grímsvötn Icelandic volcano. Remote Sens Environ 129:168-184. doi:10.1016/j.rse.2012.11.005

Maun MA (2004) Burial of plants as a selective force in sand dunes. In: Martinez ML, Psuty NP (eds) Coastal dunes, ecology and conservation, vol 171. Ecological studies. Springer, Berlin, pp 119-135. doi:10.1007/978-3-540-74002-5_8

Millennium Ecosystem Assessment (2005) Ecosystems and human well-being: synthesis. Island Press, Washington, DC

Ministry for the Environment (2007) Vernd og endurheimt íslenskra birkiskóga. Skýrsla og tillögur nefndar. (Protection and restoration of Icelandic birch forests). Reykjavik, Iceland

Mitchell JK (2006) The primacy of partnership: scoping a new national disaster recovery policy. Ann Am Acad Polit Soc Sci 604:228-255. doi:10.1177/00027162052s86044

Mitchell T, Jones L, Lovell E, Comba E (eds) (2013) Disaster risk management in post-2015 development goals: potential targets and indicators. Overseas Development Institute, London

Mori AS, Furukawa T, Sasaki T (2013) Response diversity determines the resilience of ecosystems to environmental change. Biol Rev 88:349-364. doi:10.1111/brv.12004

Munang R, Thiaw I, Alverson K, Liu J, Han Z (2013) The role of ecosystem services in climate change adaptation and disaster risk reduction. Curr Opin Environ Sustain 5:47-52. doi:10.1016/j.cosust.2013. 02.002

National Land Survey of Iceland (2009) CLC2006, CLC2000 and CLC-Changes in ICELAND. Final report national land survey of Iceland/Landmælingar Íslands

NCIP-DCPEM (2005a) Almannavarnir og áfallapol íslensks samfélags. Skýrsla almannavarnaráðs. National Commissioner of the Icelandic Police Department of Civil Protection and Emergency Management, Reykjavík

NCIP-DCPEM (2005b) Hættumat vegna eldgosa og hlaupa frá vestanverðum Mýrdalsjökli og Eyjafjallajökli (In icelandic). National Commissioner of the Icelandic Police Department of Civil Protection and Emergency Management, Háskólaútgáfan, Reykjavík

Nkonya E et al (2011) The economics of land degradation-towards an integrated global assessment, vol 66., Development economics and policyPeter Lang, Frankfurt am Main, Berlin, Bern, Bruxelles, New York, Oxford, Wien

Nytjaland, Icelandic Farmland Database (2013) Agricultural University of Iceland. http:/groa.rala.is/ Kortavefsja/default.aspx. Accessed 2013

OECD (2009) Farmland Conversion-the spatial implications of agricultural and land-use policies. OECD, Paris

OECD (2010) Agricultural policies and rural development: A synthesis of recent OECD work. OECD, Paris

Óladóttir BA, Larsen G, Sigmarsson O (2011) Holocene volcanic activity at Grímsvötn Bárdarbunga and Kverkfjöll subglacial centres beneath Vatnajökull. Iceland Bull Volcanol 73:1187-1208

Olgeirsson FG (2007) Sáðmenn sandanna: Saga landgræðslu á Íslandi 1907-2007. Landgræðsla ríkisins, Gunnarsholt

PEDRR (2010) Demonstrating the Role of Ecosystems-based Management for Disaster Risk Reduction. Background paper to the 2011 Global Assessment Report on Disaster Risk Reduction

Prime Minister's Office (2011) Ríkisstjórnin sampykkir fjárveitingar vegna fyrstu aðgerða í kjölfar eldgossins í Grímsvötnum. News, 10.6.2011. http://www.forsaetisraduneyti.is/frettir/nr/6806. Accessed 27.mars 2012

ProAct Network (2008) The role of environmental management and eco-engineering in disaster risk reduction and climate change adaptation. Ministry of the Environment, Finland, UN International Strategy for Disaster Reduction, Gaia Group

Renaud FG, Sudmeier-Rieux K, Estrella M (eds) (2013) The role of ecosystems in disaster risk reduction. United Nations University Press, Tokyo-New York-Paris 
Scheffer M, Carpenter S, Foley JA, Folke C, Walker B (2001) Catastrophic shifts in ecosystems. Nature 413:591-596

Schmidt A, Ostro B, Carslaw KS, Wilson M, Thordarson T, Mann GW, Simmons AJ (2011) Excess mortality in Europe following a future Laki-style Icelandic eruption. PNAS 108:15710-15715

Self S (2006) The effects and consequences of very large explosive volcanic eruptions. Phil Trans R Soc A 364:2073-2097

Shao Y (2000) Physics and modelling of wind erosion. Kluwer Academic, Dordrecht

Shinoda M, Gillies JA, Mikami M, Shao Y (2011) Temperate grasslands as a dust source: knowledge, uncertainties, and challenges. Aeolian Res 3:271-293

Sidle RC, Benson WH, Carriger JF, Kamai T (2013) Broader perspective on ecosystem sustainability: consequences for decision making. Proc Natl Acad Sci U S A 110:9201-9208. doi:10.1073/pnas. 1302328110

Sigmundsson F, Pinel V, Lund B, Albino F, Pagli C, Geirsson H, Sturkell E (2010) Climate effects on volcanism: influence on magmatic systems of loading and unloading from ice mass variations with examples from Iceland. Phil Trans R Soc A 368:2519-2534. doi:10.1098/rsta.2010.0042

Sigmundsson F, Hooper A et al (2015) Segmented lateral dyke growth in a rifting event at Bardarbunga volcanic system, Iceland. Nature 517(7533):191-195

Snæbjörnsson A, Hjartardóttir D, Blöndal E, Pétursson JG, Eggertsson Ó, Halldórsson Ó (2010) Skýrsla nefndar um landnotkun - Athugun á notkun og varðveislu ræktanlegs lands. Ministry of Fisheries and Agriculture, Reykjavík

Snævar S (1993) Haglýsing Íslands (economic description of Iceland). Heimskringla, Háskólaforlag Máls og menningar, Reykjavík

Steingrímsson J (1998) Fires of the Earth: the Laki eruption 1783-1784. University of Iceland Press, Reykjavík

Sudmeier-Rieux K, Ash N (2009) Environmental guidance note for disaster risk reduction: healthy ecosystems for human security. Revised Edition. IUCN, Gland, Switzerland

Swindles GT, Lawson IT, Savov IP, Connor CB, Plunkett G (2011) A 7000 years perspective on volcanic ash clouds affecting northern Europe. Geology 39:887-890. doi:10.1130/G32146.1

Tegen I, Harrison SP, Kohfeld K, Prentice IC, Coe M, Heimann M (2002) Impact of vegetation and preferential source areas on global dust aerosol: results from a model study. J Geophys Res-Atmos 107:36. doi:10.1029/2001JD000963

Thorarinsson S (1944) Tefrokronologiska studier pa Island Geografiska Annaler 26:1-217

Thorarinsson S (1958) The Öræfajökull eruption of 1362 Acta naturalia Islandica II:1-100

Thorarinsson S (1967) The eruptions of Hekla in historical times. The Eruption of Hekla 1947-1948 I. Societas Scientiarum Islandica, Reykjavik, pp 1-170

Thorarinsson S (1975) Katla og annáll Kötlugosa (Katla and its historical eruptions) Árbók Ferðafélags Íslands 1975:125-149

Thorarinsson S (1979) On the damage caused by volcanic eruptions with special reference to tephra and gases. In: Sheets PD, Grayson DK (eds) Volcanic activity and human ecology. Academic Press, New York, pp 125-159

Thordarson T, Larsen G (2007) Volcanism in Iceland in historical time: volcano types, eruption styles and eruptive history. J Geodyn 43:118-152

Thordarson T, Self S (1993) The Laki (Skaftár Fires) and Grímsvötn eruptions in 1783-1785. Bull Volcanol 55:233-263

Thordarson T, Self S (2003) Atmospheric and environmental effects of the 1783-1784 Laki eruption: a review and reassessment. J Geophys Res-Atmos 108:29. doi:10.1029/2001jd002042

Thorsteinsson T, Jóhannsson T, Stohl A, Kristiansen NI (2012) High levels of particulate matter in Iceland due to direct ash emissions by the Eyjafjallajökull eruption and resuspension of deposited ash. J Geophys Res. doi:10.1029/2011JB008756

Titus JH, Tsuyuzaki S (2003) Distribution of plants in relation to microsites on recent volcanic substrates on Mount Koma Hokkaido, Japan. Ecol Res 18:91-98. doi:10.1046/j.1440-1703.2003.00536.x

Tsuyuzaki S (2009) Causes of plant community divergence in the early stages of volcanic succession. J Veg Sci 20:959-969. doi:10.1111/j.1654-1103.2009.01104.x

Tsuyuzaki S, Hase A (2005) Plant community dynamics on the volcano Mount Koma, northern Japan, after the 1996 eruption. Folia Geobotanica 40:319-330

UNISDR (2009) United Nations 2009 UNISDR terminology on disaster risk reduction. The United Nations International Strategy for Disaster Reduction (UNISDR), Geneva

UN-ISDR (2013) The WMO disaster risk reduction. A framework for disaster risk management derived from the Hyogo framework for Action 2005-2015. World Meteorological Organization. http://www. unisdr.org/we/coordinate/hfa. Accessed 5.jan.2013 2013 
UNISDR (2011) Global assessment report on disaster risk reduction. Revealing risk redefining development summary and main findings. United Nations Office for Disaster Risk Reduction (UNISDR), Geneva

UNISDR (2015) Sendai framework for disaster risk reduction 2015-2030. A/CONF.224/CRP.1. UN World Conference on Disaster Risk Reduction. http://www.wcdrr.org/uploads/Sendai_Framework_for_ Disaster_Risk_Reduction_2015-2030.pdf. 2015

United Nations ESCAP (2013) Building resilience to natural disasters and major economic crises. United Nations Economic and Social Commission for Asia and the Pacific (ESCAP), Bangkok

Viðlagatrygging Íslands (2011) Ársskýrsla 2011. Viðlagatrygging Íslands (Iceland Catastrophe Insurance), Reykjavík

Webb NP, Strong CL (2011) Soil erodibility dynamics and its representation for wind erosion and dust emission models. Aeolian Res 3:165-179. doi:10.1016/j.aeolia.2011.03.002

Westley F et al (2011) Tipping Toward sustainability: emerging pathways of transformation. Ambio 40:762-780. doi:10.1007/s13280-011-0186-9

Wilson T, Cole J, Cronin S, Stewart C, Johnston D (2010) Impacts on agriculture following the 1991 eruption of Vulcan Hudson, Patagonia: lessons for recovery. Nat Hazards 57:185-212. doi:10.1007/ s11069-010-9604-8

Wolfe SA, Nickling WG (1993) The protective role of sparse vegetation in wind erosion. Prog Phys Geogr 17:50-68. doi:10.1177/030913339301700104

World Bank (2010) Convenient solutions to an inconvenient truth: ecosystem-based approaches to climate change. World Bank, Washington. doi:10.1596/978-0-8213-8126-7

Zobel DB, Antos JA (1987) Composition of rhizomes of forest herbaceous plants in relation to morphology, ecology, and burial by tephra. Bot Gaz 148:490-500 